\title{
A TEORIA DA NORMA JURIDICA DE N. BOBBIO E O DIREITO PENAL BRASILEIRO
}

Ela Wiecko Wolkmer de Castilho

O trabalho proposto objetiva um exame da teoria da norma jurídica formulada por Norberto Bobbio em relação ao Direito Penal Brasileiro.

A teoria da norma jurídica de N. Bobbio encontra-se desenvolvida na obra Teoria della Norma Giuridica, fruto de um curso prelecionado no ano de 1958.

Lá ele fixa o critério distintivo da norma jurídica através da sanção e a sanção jur ídica através dos caracteres da exterioridade e da institucionalização (p. 197 e ss), donde a definição da norma jurídica como aquela "cuja execução é garantida de uma sanção externa e institucionalizada". (p. 198) ${ }^{1}$.

A norma jurídica não tem, portanto, uma estrutura interna que a diferencie das demais normas de conduta. Ela é jurídica porque faz parte de um complexo organizado de normas, isto é, de um sistema ou de um ordenamento que é jurídico.

Definir o jurídico, definir o direito é então um problema de definição do que é um ordenamento jurídico. Por isso posteriormente, N. Bobbio escreveu a Teoria dell'Ordinamento Giuridico.

Para distinguir um ordenamento jurídico daquele que não o é, $\mathrm{N}$. Bobbio não nos dá uma resposta concludente, reconhecendo ser necessário sair da perspectiva puramente formal (p. 255) ${ }^{2}$. a qual, no entanto, não ousou abandonar nas duas obras referidas.

Deixa claro, porém, que num ordenamento jurídico há uma complexa organização de normas e de sanções, há uma atribuição de competência para executá-las e a própria execução é regulada.

Parecem-nos relevantes as considerações que faz sobre as normas desprovidas de sanção. São jurídicas, desde que façam parte de um complexo em que a maioria das normas sejam sancionadas. Assinala que as normas superiores na hierarquia normativa de um ordenamento jur ídico, como é o caso, das normas constitucionais, justamente as mais importantes do sistema, são desprovidas de sanção. 
Explica que isto não é absurdo e não enfraquece sua definição de direito. É que a aplicação da sanção pressupõe a existência de um apareIho coercitivo e este o poder.

As normas superiores estão mais próximas da fonte do poder, não sendo possível, porque contraditório, que a fonte do poder esteja sujeita à coação.

Ao passar das normas inferiores de um ordenamento àquelas superiores distinguimos um momento em que a força destinada a aplicar o direito passa a produz í-lo, ou seja, um plano em que o conceito de força como sanção de um direito já estabelecido se transforma num conceito de força como produção de um direito futuro. (p. 210$)^{3}$

Essa inversão da relação direito-força ocorre em um ponto da hierarquia de normas existentes no ordenamento, jurídico que N. Bobbio não sabe precisar . . . Mas, é certo que no plano mais baixo a força está a serviço do direito e no mais alto o direito está a serviço da força.

Nesse raciocínio talvez fosse o caso de indagar qual a diferença ontológica entre direito e força, binômio também conhecido sob a relação direito e poder. A transmutação que se observa do poder em direito não seria apenas fenomenológica, mascarando a verdadeira realidade a ser estudada? Qual a diferença entre o jurídico e o político?

Quando as normas superiores do sistema não são seguidas, Bobbio diz que não ocorre violação, mas a produção de uma norma nova, isto é, uma modificação do sistema.

A seu ver o direito público europeu apresenta uma tendência em sancionar cada vez mais as normas, da base ao vértice do sistema, tornando-se mais jur ídico. Assim, o Estado de Direito é um estado em que o controle jurídico se alargou. (p. 212) ${ }^{4}$.

Essas colocações sumariamente expostas nos conduzem a um fértil campo de investigações no aspecto do Direito Penal, ramo que é, ou subsistema do ordenamento jurídico.

Em primeiro lugar ressalta o fato de que o conjunto de normas que constituem o Direito Penal Brasileiro, como de resto qualquer Direito penal pertencente a outro ordenamento jurídico, é eminentemente sancionatório.

A norma penal, em conseqüência lógica da sua qualidade valorativa - é sancionadora em sentido lógico, isto é, escolhe os preceitos depois que outros ramos jurídicos falharam com as suas sanções específicas (repositivas e reparativas), assim quando há um impedimento fático (homicídio) ou ético (furto) de repor ou de reparar, 'o direito penal intervém com a sua gama de sanções retributivas (porque vinculadas à censurabilidade pessoal do agente, referida ao fato isolado cometido) ${ }^{5}$

Pode-se então dizer que as normas penais estão num plano em que a força está a serviço do direito e sua tendência é retrógada, porque tende a perpetuar a força, o poder, que originariamente produziu o direito.

O Direito Penal exerce, pois, uma função ideológica.

Um dos traços fundamentais da ideologia consiste em tomar as idéias como independentes da realidade histórica e social, de modo a fa- 
zer com que tais idéias expliquem aquela realidade, quando na verdade é essa realidade que torna compreensíveis as idéias elaboradas. ${ }^{6}$

O Direito penal exerce uma função ideológica na medida em que é tomado como objeto de conhecimento, como por exemplo, quando é estudado como um conjunto de normas orgânico, integrado, completo, real em sí.

Essa atitude epistemológica não leva à verdade. E a teorização de $\mathrm{N}$. Bobbio, ainda que numa linha formal, despreocupada com o aspecto ideológico, acaba por fundamentar e reforçar as conclusões de nosso trabalho anterior ${ }^{7}$ em que salientamos que a estreita ligação entre Direito Penal e Estado (poder organizado), mostrando como a evolução do conceito e da função estatal implica em correspondente evolução do conceito e da função do Direito Penal.

Daí porque concluimos nesse trabalho que o problema da pena é político e no exame específico do projeto da reforma penal brasileira entendemos que a criação de novas normas e a transformação das existentes significa apenas uma maneira de manter as relações de poder existentes e não de transformação dessa estrutura política.

\section{REFERÊNCIAS BIBLIOGRÁFICAS}

1. BOBBIO, Norberto. Teoria della Norma Giuridica.

2.idem

3.idem

4.idem

5. MACHADO, Luiz Alberto. Direito Penal. No Prelo.

6. CHAUÍ, Marilena. O que é Ideologia. São Paulo, Brasiliense, 1983, 12 a edição, p. 10.

7. Teorias Atuais da Pena e o Projeto de Reforma Penal Brasileiro. 